\title{
Occurrence of Volatile and Semi-Volatile Organic Pollutants in the Russian Arctic Atmosphere: The International Siberian Shelf Study Expedition (ISSS-2020)
}

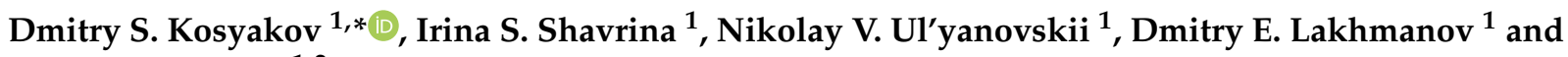 \\ Albert T. Lebedev 1,2,* \\ 1 Laboratory of Environmental Analytical Chemistry, Core Facility Center "Arktika", Northern (Arctic) Federal \\ University, 163002 Arkhangelsk, Russia; i.shavrina@narfu.ru (I.S.S.); n.ulyanovsky@narfu.ru (N.V.U.); \\ d.lahmanov@narfu.ru (D.E.L.) \\ 2 Department of Organic Chemistry, Lomonosov Moscow State University, 119991 Moscow, Russia \\ * Correspondence: d.kosyakov@narfu.ru (D.S.K.); mocehops@yandex.ru (A.T.L.)
}

Citation: Kosyakov, D.S.; Shavrina, I.S.; Ul'yanovskii, N.V.; Lakhmanov, D.E.; Lebedev, A.T. Occurrence of Volatile and Semi-Volatile Organic Pollutants in the Russian Arctic Atmosphere: The International Siberian Shelf Study Expedition (ISSS-2020). Atmosphere 2021, 12, 767. https://doi.org/10.3390/ atmos12060767

Academic Editors: Evangelos Tolis and Marco Grotti

Received: 28 April 2021

Accepted: 11 June 2021

Published: 14 June 2021

Publisher's Note: MDPI stays neutral with regard to jurisdictional claims in published maps and institutional affiliations.

Copyright: (c) 2021 by the authors. Licensee MDPI, Basel, Switzerland. This article is an open access article distributed under the terms and conditions of the Creative Commons Attribution (CC BY) license (https:/ / creativecommons.org/licenses/by/ $4.0 /)$.

\begin{abstract}
Environmental issues in the Arctic region are of primary importance due to the fragility of the Arctic ecosystem. Mainly persistent organic compounds are monitored in the region by nine stationary laboratories. Information on the volatile (VOC) and semi volatile (SVOC) organic priority pollutants is very limited, especially for the Russian Arctic. Air samples from 16 sites along the Russian Arctic coast from the White Sea to the East Siberian Sea were collected on sorption tubes packed with Tenax, Carbograph, and Carboxen sorbents with different selectivity for a wide range of VOCs and SVOCs in 2020 within the framework of the International Siberian Shelf Study Expedition on the research vessel Akademik Keldysh. Thermal desorption gas chromatography-high-resolution mass spectrometry with Orbitrap was used for the analysis. Eighty-six VOCs and SVOCs were detected in the air samples at $\mathrm{ng} / \mathrm{m}^{3}$ levels. The number of quantified compounds varied from 26 to 66 per sample. Benzoic acid was the major constituent, followed by BTEX, phenol, chloroform, bis(2-ethylhexyl) phthalate, and carbon tetrachloride. The study allowed for obtaining the first ever data on the presence of 138 priority pollutants in the air of Russian Arctic, whereas the thorough assessment of their possible sources will be the aim of a next investigation.
\end{abstract}

Keywords: Russian Arctic; Arctic ocean; air pollution; volatile organic compounds; semi-volatile organic compounds; gas chromatography; high-resolution mass spectrometry; thermal desorption

\section{Introduction}

Global warming and ice melting makes the Arctic region more and more attractive for economic use [1], including the development of transport arteries (Northern Sea Route), hydrocarbon production on the shelf, and the development of mineral deposits in the mainland zone and on the Arctic islands. Such an increase in human economic activity inevitably leads to the corresponding increase in anthropogenic load on the fragile Arctic ecosystem, including air pollution with toxic volatile (VOCs) and semi-volatile (SVOCs) organic compounds [2]. In addition to local sources of emissions, global circulation of the atmosphere plays a huge role and ensures the transport of toxic compounds over long distances [3-5] and their accumulation in the snow cover and soil due to condensation ("cold finger" effect) [6]. Natural processes can also play a significant role in changing the chemical composition of the atmosphere at high latitudes. These include the release of VOCs from melting permafrost and an increase in their biogenic emission from tundra ecosystems [7,8], transfer of biogenic compounds with aerosol particles [9], as well as the combustion of large volumes of biomass during forest and peat fires [10-12] due to an increase in average temperature and drying out of sub-Arctic peat bogs, accumulating a significant part of the world's biomass resources. 
The study of the chemical composition of the Arctic air and its temporal trends is an important task. Its solution contributes to a deeper understanding of chemical processes in the atmosphere of the polar regions, their impact on climate change and the state of the ozone layer, as well as the assessment of risks for Arctic ecosystems and human health. Nevertheless, the currently available literature data on the chemical composition and levels of atmospheric pollutants at high latitudes are notably incomplete. Most of the earlier studies were focused mainly on the determination of the major gaseous pollutants (nitrogen and sulfur oxides, carbon monoxide and dioxide, ozone, methane), particulate matter, and black carbon, present in relatively high levels and being of paramount importance from the climatology point of view $[13,14]$. Within the framework of the international project "Arctic Monitoring and Assessment Program (AMAP)" [15] persistent organic pollutants (POP) and chemicals of emerging Arctic concern (CEAC) [16] as the most dangerous micropollutants have been monitored in the Arctic environment for many years. These include organochlorine pesticides (OCs), polychlorinated biphenyls (PCBs), polyfluoroalkyl substances (PFAS), polybrominated diphenyl ethers (PBDEs), long-chain perfluorocarboxylic acids (PFCAs), perfluorohexane sulfonic acid (PFHxS), and some other fluorinated compounds [17]. Air sampling (polyurethane and XAD-2 resin samplers) for subsequent GC-MS analysis is carried out at nine stations located in Canada (2), Greenland (1), Iceland (1), Norway (2), Finland (1), and Russia (2). Considerable attention has been also paid to polycyclic aromatic hydrocarbons (PAHs), as their concentrations in the Arctic atmosphere do not decrease despite the global industrial emission reduction due to the large contribution of natural sources (biomass combustion) [18].

The most recent publication by Pernov et al. [19] was focused on studying the temporal trends of ten key VOCs in the Greenland atmosphere using proton transfer ionization timeof-flight mass spectrometry. The significant role of biomass combustion in the pollution of the Arctic air was noted, as well as the contribution of ice melting, leading to the emission of dimethyl sulfide and lower organic acids.

The range of detected atmospheric pollutants in the Arctic is constantly expanding as new data are being accumulated and more advanced analytical methods are being introduced. Numerous novel compounds of various classes have been included in the list of potential CEACs recently [20]. The studies of Arctic snow as a deposition matrix for airborne pollutants using high-resolution mass spectrometry have revealed hundreds of VOCs and SVOCs, many of which are potentially hazardous [21-23]. These include, for example, pyridine and its alkylated derivatives, arising mainly due to peat fires [11].

Surprisingly, the published data still lack reliable information on the levels of the most common regulated VOCs and SVOCs in the Arctic air. EPA methods 8260 and 8270 were designated for their analysis [24,25]. These are numerous halogenated alkanes and alkenes, aromatic hydrocarbons and their halogenated derivatives, phenols and chlorophenols, some nitrogen-containing compounds, phthalic acid esters, and PAHs. This situation is associated with the inaccessibility of field studies at high latitudes, problems of sampling and transporting large volumes of air for laboratory analysis due to low concentrations of analytes, and insufficient sensitivity of the analytical methods currently used.

The present study was carried out within the framework of the International Siberian Shelf Study Expedition (ISSS-2020) project with the research vessel Akademik Keldysh in the fall of 2020 in the White, Barents, Kara, East Siberian, and Laptev Seas. The principal aim of the study involved obtaining the first ever set of data on the levels of a wide range of VOCs and SVOCs in the atmosphere of the Russian Arctic. To achieve that goal, the advanced technique of thermal desorption gas chromatography-high-resolution mass spectrometry (TD-GC-HRMS) with an orbital ion trap (Orbitrap) mass analyzer providing exceptional sensitivity and selectivity of the analysis was used. 


\section{Materials and Methods}

\subsection{Air Samplng}

Sampling was carried out from 28 September to 1 November 2020, at 16 points along the mainland coast, covering the entire Russian sector of the Arctic from the White Sea to the East Siberian Sea (Figure 1) at latitudes of $65-78^{\prime}$. The exact coordinates and sampling conditions are presented in the Supplementary material (Table S1). The samples were collected during the ship motion from the outer side of the upwind board at a height of about $10 \mathrm{~m}$ above the water level only in favorable weather conditions-the absence of a storm in order to avoid the ingress of excessive amounts of water aerosol into the sorption tube and the presence of a constant wind to exclude the interferences from volatile compounds emitted from the technical and domestic systems of the vessel. Only one air sample was taken at each sampling point. Using an ActiVOC aspirator (Markes, Bridgend, UK), approximately $2 \mathrm{~L}$ of air was pumped at a rate of $50 \mathrm{~mL} / \mathrm{min}$ through a preconditioned $\left(300{ }^{\circ} \mathrm{C}, 2 \mathrm{~h}\right)$ stainless-steel three-bed «Universal» sorption tube (Markes, Bridgend, UK), $31 / 2^{\prime \prime} \times 1 / 4^{\prime \prime}$ o.d., packed with Tenax TA, Carbograph 1TD, and Carboxen 1003 sorbents with different selectivity ensuring trapping a wide range of VOCs and SVOCs (typically, C3-C30). Immediately after sampling, the sorption tube was tightly capped with a brass long-term storage cap and placed in a freezer $\left(-20^{\circ} \mathrm{C}\right)$ for $1-2$ months until laboratory analysis. The blank sorption tube was prepared and stored in the same manner excluding air pumping. Analytes were considered to be detected in air samples if the ratio of their signal intensities in the sample and blank chromatograms were $>10$. An additional sample was collected on the deck and in the premises of the vessel and then analyzed with other samples. The clear difference in the chemical composition of this sample and the studied Arctic air samples provided additional evidence of the absence of their significant contamination.

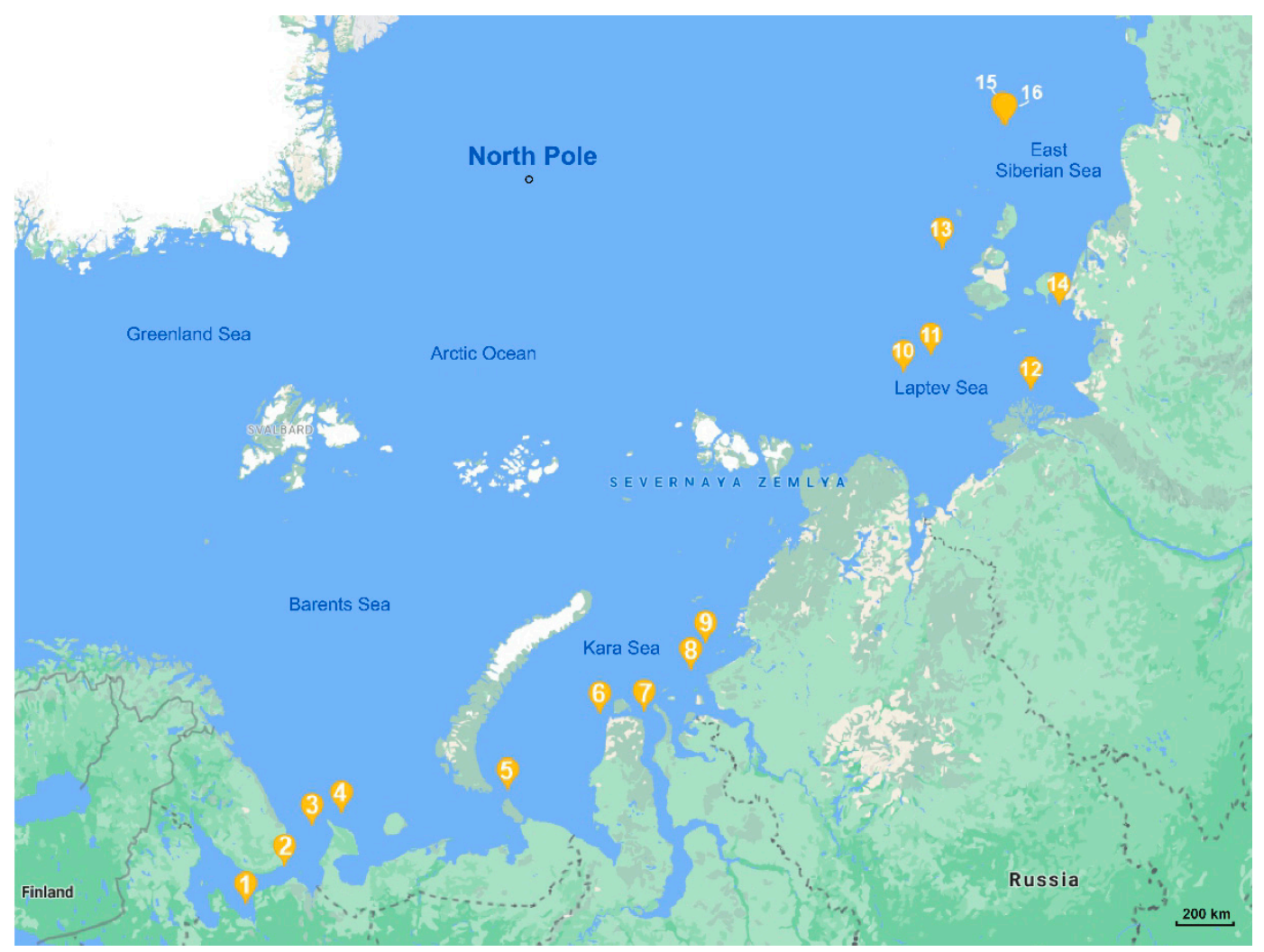

Figure 1. Air sampling sites during ISSS-2020 expedition. 


\subsection{TD-GC-HRMS Analysis}

TD-GC-HRMS analysis was carried out using a Unity XR thermal desorber (Markes, Bridgend, UK) combined with an Exactive GC system (Thermo Scientific, Waltham, MA, USA), which consisted of a Trace 1310 gas chromatograph and Orbitrap high-resolution mass spectrometer. Prior to heating, the sorption tube with a sample was flushed with carrier gas (helium, 99.9999\%) with a flowrate of $30 \mathrm{~mL} / \mathrm{min}$ for $1 \mathrm{~min}$ to remove excess moisture interfering with the GC separation. Thermal desorption of adsorbed analytes was carried out in a flow of carrier gas at $280{ }^{\circ} \mathrm{C}$ during $10 \mathrm{~min}$ with further focus on a cooled $\left(10^{\circ} \mathrm{C}\right)$ trap with a general purpose carbon adsorbent and additional flushing of the trap with helium $(5 \mathrm{~min}, 10 \mathrm{~mL} / \mathrm{min})$. Preliminary experiments have shown that complete desorption of all analytes was achieved, and the introduction of additional stages of purging the sorption tube and the trap under the indicated conditions did not lead to a noticeable loss of even volatile analytes; however, it made it possible to significantly improve the shape of the chromatographic peaks of some compounds, which is distorted when residual moisture enters the column. The sample was introduced into the GC column by the flash heating the trap to $320^{\circ} \mathrm{C}(1 \mathrm{~min}$ hold $)$ with a split $1: 5$. The analytes in the split flow $(80 \%)$ were recollected on a second sorption tube with the same sorbents for re-analysis.

Chromatographic separation was achieved on a TG-5SilMS fused silica capillary column (Thermo Scientific, Waltham, USA), $30 \mathrm{~m} \times 0.25 \mathrm{~mm}, 0.25 \mu \mathrm{m}$ film thickness, with a (5\%-phenyl)-methylpolysiloxane stationary phase. The oven temperature was programmed from $40{ }^{\circ} \mathrm{C}$ (held for $4 \mathrm{~min}$ ) to $300^{\circ} \mathrm{C}$ (held for $12 \mathrm{~min}$ ) at the $6{ }^{\circ} \mathrm{C} / \mathrm{min}$ ramp. Total duration of the analysis was $60 \mathrm{~min}$. The temperatures of the ion source and transfer line between GC and MS were 200 and $300^{\circ} \mathrm{C}$, respectively.

Mass spectrometry detection was carried out in full scan mode in $\mathrm{m} / \mathrm{z}$ range 40-500 at a spectral resolution of $30,000(\mathrm{M} / \Delta \mathrm{M}$, full width at half maximum, at $m / z 200)$ and $12 \mathrm{~Hz}$ data acquisition frequency. Electron ionization $(70 \mathrm{eV})$ was used. Mass scale calibration was performed daily using perfluorotributylamine (PFTBA) as a standard to achieve mass accuracy below 3 ppm (typically $<1 \mathrm{ppm}$ ). An automatic gain control (AGC) with the curved quadrupole ion trap (C-Trap) target filling value of $10^{5}$ was used. The control of the GC-MS system, the collection, and preprocessing of the data were performed using Xcalibur 4.1 software (Thermo Scientific, Waltham, USA).

\subsection{Analytes and Their Quantification}

One hundred and thirty-eight VOCs and SVOCs included in EPA method 8260B Calibration Mix \#1 and EPA method 8270 MegaMix (Restek, Bellefonte, PA, USA), respectively, were chosen as target analytes (Supplementary Tables S2 and S3). Benzoic acid (>99\% purity), purchased from Sigma-Aldrich, was also used as a standard.

Standard solutions of analytes in dichloromethane ( $>99.8 \%$, PanReac, Barcelona, Spain) were prepared by consecutive dilutions of the EPA methods $8260 \mathrm{~B}$ and 8270 standard mixtures and stock solution of benzoic acid to obtain concentrations of $0.1,1,2.5,6.25$, 10 , and $25 \mathrm{mg} / \mathrm{L}$. System calibration was performed by micro-syringe injection of $2 \mu \mathrm{L}$ of each calibration solution into the pre-conditioned sorption tube with high-purity $(99.999 \%)$ nitrogen flow $(50 \mathrm{~mL} / \mathrm{min}$ ) using a CSLR calibration solution loading rig (Markes, Bridgend, UK) with further TD-GC-HRMS analysis. The calibration plots were constructed in the analyte's weight injected (0.2-50 ng)-chromatographic peak area coordinates. They were linear $\left(r^{2}>0.99\right)$ in the entire concentration range. The most intense peaks in mass spectra of analytes (typically belonging to molecular ions $[\mathrm{M}]^{+}$) were used for quantification. An $\mathrm{m} / \mathrm{z}$ window width for extracted ion current (XIC) chromatograms for each analyte of $5 \mathrm{ppm}$ was used, ensuring high selectivity of the analysis, low background noise level, and thus higher sensitivity. Limits of detection (LODs) and quantification (LOQs) were calculated on the basis of a signal-to-noise ratio criteria of 3 and 10, respectively. Full-range highresolution mass spectra and home-made target analytes spectral library search were used for the confirmation purposes. All quantification procedures were carried out using the 
TraceFinder software (Thermo Scientific, Waltham, USA). For the multivariate data analysis, the Origin software (OriginLab, Northampton, MA, USA) was used. The uncertainty of the TD-GC-MS analysis was estimated by the repetitive analyses of recollected samples and did not exceed $10 \%$.

\section{Results and Discussion}

\subsection{Method Sensitivity and General Description of the Samples}

The combination of sorptive preconcentration of analytes with the use of the Orbitrap high-resolution instrument characterized by exceptionally high sensitivity in the full mass spectrum scanning mode made it possible to work with small volumes of air samples ( 2-3 L) and avoiding problems with their sampling and interferences from atmospheric moisture. Typically, the obtained LODs presented in Supplementary material (Tables S2 and S3) lay in the range of $1-100 \mathrm{pg}$ on tube or $0.5-50 \mathrm{ng} / \mathrm{m}^{3}$ in air (recalculated for the sample volume of $2 \mathrm{~L}$ ). Such sensitivity is not attainable when using TD-GC-MS systems with low-resolution mass analyzers due to the increased chemical background noise associated with the release of sorbent decomposition products with $m / z$ values close to that of analytes. Only 10 analytes (three VOCs and seven SVOCs) have their LODs $>0.1 \mathrm{pg}$ on tube, with the highest value observed for 2,4 -dinitrophenol $-0.85 \mathrm{pg}$ on tube or $0.43 \mu \mathrm{g} / \mathrm{m}^{3}$.

The obtained chromatograms (Figures S1-S16, an example is presented in Figure 2) demonstrate good separation of analytes and high signal-to-noise ratios, providing reliable quantification of the vast majority of target compounds-out of 138 analytes, only 52 were not detected in any sample. The number of compounds that could be quantified varied from 26 (sample 1) to 66 (sample 9). At the same time, 10-20 peaks on each chromatogram referring to major components were characterized by high relative signal intensities $(>10 \%)$. In most chromatograms, benzoic acid (compound 97) had the highest signal intensity providing a broadened peak due to the presence of a free carboxyl group (as a rule, derivatization is required to improve the shape of the peaks of carboxylic acids) [26]. It should be noted that the obtained concentrations of the analytes were far below the safe levels established in Russia [27]. The special cases of BTEX and phenol are discussed below.

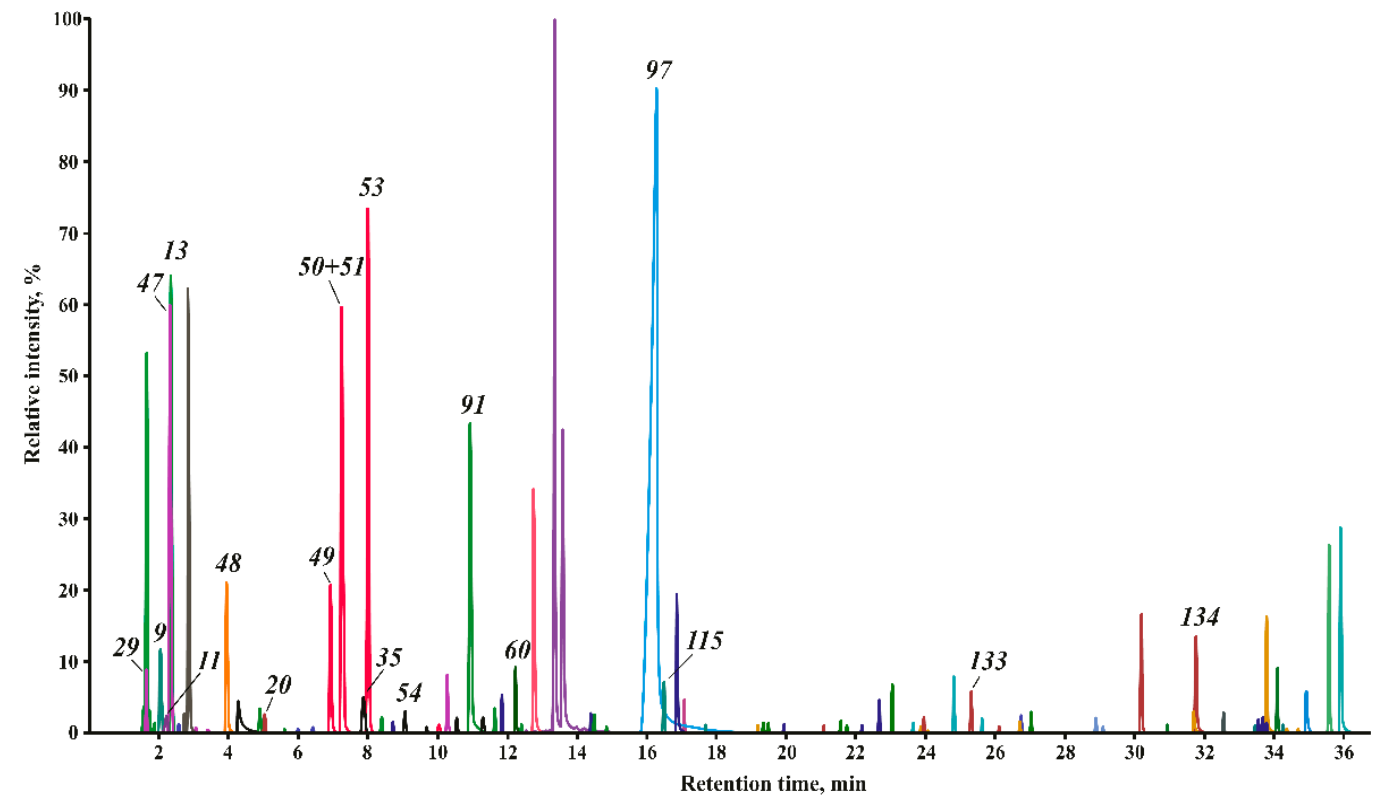

Figure 2. Reconstructed XIC chromatogram of the target analytes in air sample No. 5 (peak numbers correspond to compound numbers in the Tables). 


\subsection{Volatile Organic Compounds}

Among VOCs, representatives of three groups of compounds were detected in the studied air samples-halogenated aliphatic hydrocarbons (alkanes, alkenes), aromatic hydrocarbons, and their halogenated derivatives (Table 1). The first two groups were predominant, and their representatives were found in comparable quantities (for most samples $\left.1-36 \mu \mathrm{g} / \mathrm{m}^{3}\right)$. The total content of halogenated aromatic hydrocarbons turned out to be $2-3$ orders of magnitude lower, and in the case of samples $3,6,10$, and 14, the concentrations of none of them exceeded LOQ value (Figure 3).

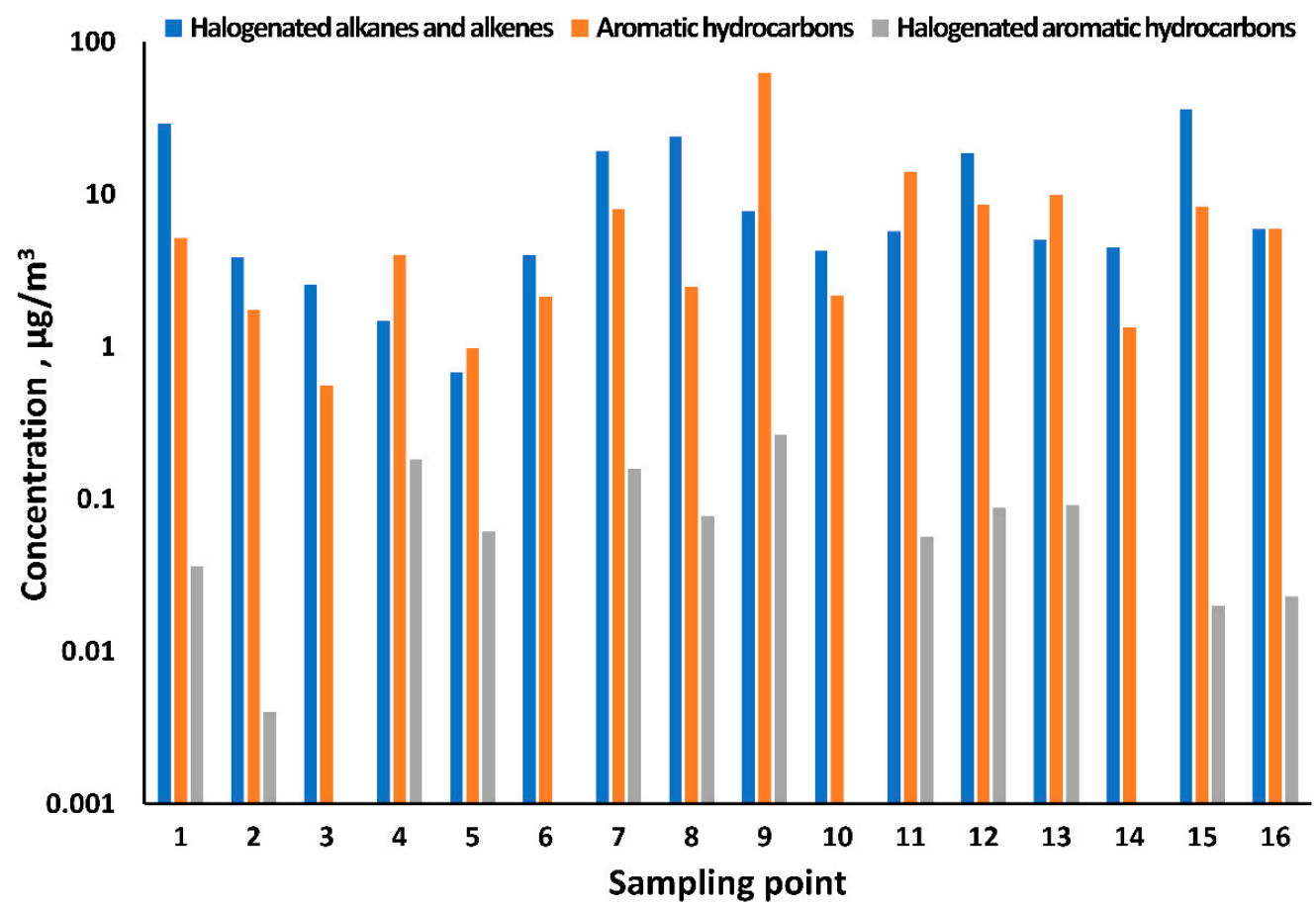

Figure 3. The sum concentrations of VOC groups in the studied air samples.

The first group was dominated by 1,1,2-trichlorotrifluoroethane (CFC-113, Freon 113), which is still widely used as a refrigerant and has a high ozone-depleting potential. Despite the abandonment of its production, the concentration of this compound in the atmosphere decreases very slowly and at present its molar fraction in the tropospheric air averages $70-80 \mathrm{ppt}$, which corresponds to a level of $\sim 0.5 \mu \mathrm{g} / \mathrm{m}^{3}[28,29]$. The concentrations measured in this study at most sampling points were slightly higher $\left(1-5 \mu \mathrm{g} / \mathrm{m}^{3}\right)$, and at five points $(1,7,8,12,15)$ turned out to be considerably high $\left(18-35 \mu \mathrm{g} / \mathrm{m}^{3}\right)$. It is noteworthy that these sampling sites corresponded to the mouth zones of large rivers (Northern Dvina, Ob, Yenisei, Lena) flowing through industrial centers and were close to the ports on the Arctic Ocean coast. Other halogenated aliphatic hydrocarbons were represented mainly by carbon tetrachloride $\left(0.7-1.7 \mu \mathrm{g} / \mathrm{m}^{3}\right)$, chloroform $\left(0.1-1.9 \mu \mathrm{g} / \mathrm{m}^{3}\right)$, and 1,2-dichloroethane $\left(0.1-0.3 \mu \mathrm{g} / \mathrm{m}^{3}\right)$. Tetrachloroethene, 1,2-dichloropropane, 1,1,1- and 1,1,2-trichloroethane were also found in low concentrations comparable to their LOQ.

The detection of appreciable amounts of bromoalkanes is of particular interest. Bromoform $\left(0.01-0.23 \mu \mathrm{g} / \mathrm{m}^{3}\right)$, present in all selected samples, and dibromomethane $\left(0.03-0.07 \mu \mathrm{g} / \mathrm{m}^{3}\right)$, detected in 12 air samples, predominated among them. These compounds have already been repeatedly found worldwide in the marine environment [30,31], including the Arctic snow [21,22]. They are of biogenic origin associated with the vital activity of macroalgae, phytoplankton, bacteria, and photochemical processes in the surface layer of the ocean [32,33]. Traces of bromochloromethanes found in some samples have the same origin [33]. It is worth noting that along with some other halogenated compounds, bromoform is included into the CEAC list [34]. 
Table 1. Concentrations of volatile organic compounds in the air samples measured by TD-GC-HRMS.

\begin{tabular}{|c|c|c|c|c|c|c|c|c|c|c|c|c|c|c|c|c|c|c|}
\hline \multirow{2}{*}{ Number } & \multirow{2}{*}{ Compounds } & \multirow{2}{*}{$\operatorname{Tr}, \min$} & \multicolumn{16}{|c|}{ Concentration, $\mu \mathrm{g} / \mathrm{m}^{3}$ at Sampling Point No. } \\
\hline & & & 1 & 2 & 3 & 4 & 5 & 6 & 7 & 8 & 9 & 10 & 11 & 12 & 13 & 14 & 15 & 16 \\
\hline \multicolumn{19}{|c|}{ Cl-alkanes, Cl-alkenes } \\
\hline 1 & Allyl chloride & 1.53 & - & - & - & - & - & - & - & - & - & - & - & - & - & - & - & - \\
\hline 3 & 1,1-Dichloroethene & 1.75 & - & - & - & - & - & - & - & - & - & - & - & - & - & - & - & - \\
\hline 4 & 1,1-Dichloroethane & 1.81 & - & $<0.017$ & $<0.017$ & - & - & $<0.017$ & - & - & $<0.017$ & $<0.017$ & 0.019 & - & $<0.017$ & $<0.017$ & - & - \\
\hline 5 & Chloroprene & 1.85 & - & - & - & - & - & - & - & - & - & - & & - & - & - & - & - \\
\hline 6,7 & cis and trans -1,2-Dichloroethene & 1.93 & - & - & - & - & - & - & - & - & - & - & $<0.033$ & - & - & - & - & - \\
\hline 8 & 2,2-Dichloropropane & 1.98 & - & - & - & - & - & - & - & - & - & - & - & - & - & - & - & - \\
\hline 9 & Chloroform & 2.02 & - & 0.36 & 0.17 & 0.12 & 0.014 & 0.22 & - & - & 1.9 & 0.29 & 0.42 & - & 0.40 & 0.26 & & \\
\hline 11 & 1,2-Dichloroethane & 2.25 & - & 0.24 & 0.14 & 0.17 & 0.018 & 0.16 & - & - & 0.34 & 0.17 & 0.27 & - & 0.25 & 0.16 & - & - \\
\hline 12 & 1,1-Dichloropropene & 2.26 & - & - & - & - & - & - & - & - & - & - & - & - & - & - & - & - \\
\hline 13 & Carbon tetrachloride & 2.33 & 1.1 & 1.2 & 0.89 & 0.72 & 0.25 & 1.2 & - & 0.1 & 1.7 & 1.4 & 1.8 & 0.26 & 1.5 & 1.4 & 0.62 & 0.65 \\
\hline 14 & Trichloroethene & 2.73 & 0.005 & - & - & - & - & - & - & $<0.005$ & 0.009 & - & 0.023 & $<0.005$ & $<0.005$ & $<0.005$ & 0.007 & 0.007 \\
\hline 15 & 1,2-Dichloropropane & 2.75 & 0.044 & 0.053 & 0.034 & 0.053 & 0.017 & 0.039 & - & 0.020 & 0.074 & 0.029 & 0.060 & 0.040 & 0.045 & 0.029 & 0.031 & 0.026 \\
\hline 16 & cis-1,3-Dichloropropene & 3.36 & - & - & - & - & - & - & - & - & - & - & - & - & - & - & - & - \\
\hline 17 & trans-1,3-Dichloropropene & 3.95 & - & - & - & - & - & - & - & - & - & - & - & - & - & - & - & - \\
\hline 18 & 1,1,2-Trichloroethane & 4.19 & $<0.017$ & $<0.017$ & $<0.017$ & $<0.017$ & $<0.017$ & $<0.017$ & - & $<0.017$ & $<0.017$ & $<0.017$ & $<0.017$ & $<0.017$ & $<0.017$ & $<0.017$ & $<0.017$ & $<0.017$ \\
\hline 19 & 1,3-Dichloropropane & 4.40 & - & - & - & - & - & - & - & - & - & - & & & - & & & . \\
\hline 20 & Tetrachloroethene & 4.99 & 0.048 & 0.054 & 0.039 & 0.090 & 0.037 & 0.038 & 0.058 & 0.042 & 0.087 & 0.045 & 0.18 & 0.020 & 0.20 & 0.040 & 0.070 & 0.053 \\
\hline 21 & 1,1,1,2-Tetrachloroethane & 6.61 & - & - & - & - & - & - & - & - & - & - & - & - & - & - & - & - \\
\hline 22 & cis-1,4-Dichloro-2-butene & 8.42 & - & - & - & - & - & - & - & - & - & - & - & - & - & - & - & - \\
\hline 25 & trans-1,4-Dichloro-2-butene & 9.17 & - & - & - & - & - & - & - & - & - & - & - & - & - & - & - & - \\
\hline 26 & Pentachloroethane & 10.80 & - & - & - & - & - & - & - & - & - & - & - & - & - & - & - & - \\
\hline 27 & Hexachloro-1,3-butadiene & 8.93 & 0.003 & 0.004 & 0.004 & 0.017 & 0.003 & 0.004 & 0.017 & 0.006 & 0.010 & 0.005 & 0.005 & 0.003 & 0.006 & 0.005 & 0.004 & 0.004 \\
\hline 28 & Iodomethane & 1.61 & - & - & - & - & - & - & - & - & - & - & - & - & - & - & - & - \\
\hline 29 & $\begin{array}{l}\text { 1,1,2-Trichlorotrifluoroethane } \\
\text { (CFC-113) }\end{array}$ & 1.61 & 28 & 1.8 & 1.2 & $<0.075$ & 0.1 & 2.2 & 19 & 24 & 3.4 & 2.2 & 2.8 & 18 & 2.5 & 2.4 & 35 & 5.1 \\
\hline 30 & Bromochloromethane & 2.01 & - & $<0.027$ & $<0.027$ & - & - & $<0.027$ & - & - & - & $<0.027$ & $<0.027$ & - & $<0.027$ & $<0.027$ & - & - \\
\hline 31 & Dibromomethane & 2.78 & - & 0.037 & 0.033 & 0.07 & 0.015 & 0.027 & - & $<0.008$ & 0.055 & 0.027 & 0.034 & $<0.008$ & 0.04 & 0.033 & 0.014 & 0.009 \\
\hline 32 & Bromodichloromethane & 2.89 & - & 0.008 & $<0.008$ & 0.013 & $<0.008$ & $<0.008$ & - & $<0.008$ & 0.009 & $<0.008$ & 0.009 & $<0.008$ & 0.008 & $<0.008$ & $<0.008$ & $<0.008$ \\
\hline 33 & Dibromochloromethane & 4.84 & $<0.010$ & $<0.010$ & $<0.010$ & 0.012 & 0.012 & $<0.010$ & - & $<0.010$ & 0.015 & $<0.010$ & $<0.010$ & $<0.010$ & $<0.010$ & $<0.010$ & $<0.010$ & $<0.010$ \\
\hline 34 & 1,2-Dibromoethane (EDB) & 5.13 & - & - & - & - & - & - & - & - & - & - & - & - & - & - & - & - \\
\hline 35 & Bromoform & 7.88 & 0.024 & 0.095 & 0.090 & 0.19 & 0.23 & 0.047 & 0.012 & 0.017 & 0.1 & 0.049 & 0.058 & 0.013 & 0.068 & 0.058 & 0.018 & 0.019 \\
\hline \multicolumn{19}{|c|}{ N-compounds } \\
\hline 36 & Acrylonitrile & 1.61 & - & - & - & - & - & - & - & - & - & - & - & - & - & - & - & - \\
\hline 37 & Propionitrile & 1.78 & - & - & - & - & - & - & - & - & - & - & - & - & - & - & - & - \\
\hline 38 & Methacrylonitrile & 1.93 & - & - & - & - & - & - & - & - & - & - & - & - & - & - & - & - \\
\hline 39 & Nitrobenzene & 13.92 & - & - & - & - & - & - & - & - & - & - & - & - & - & - & - & - \\
\hline
\end{tabular}


Table 1. Cont.

\begin{tabular}{|c|c|c|c|c|c|c|c|c|c|c|c|c|c|c|c|c|c|c|}
\hline \multirow{2}{*}{ Number } & \multirow{2}{*}{ Compounds } & \multirow{2}{*}{$\operatorname{Tr}, \min$} & \multicolumn{16}{|c|}{ Concentration, $\mu \mathrm{g} / \mathrm{m}^{3}$ at Sampling Point No. } \\
\hline & & & 1 & 2 & 3 & 4 & 5 & 6 & 7 & 8 & 9 & 10 & 11 & 12 & 13 & 14 & 15 & 16 \\
\hline \multicolumn{19}{|c|}{ S-compounds, O-compounds } \\
\hline 40 & Carbon disulfide & 1.66 & - & - & - & - & - & - & - & - & - & - & - & - & - & - & - & - \\
\hline 42 & Isobutyl alcohol & 2.04 & - & - & - & - & - & - & - & - & - & - & - & - & - & - & - & - \\
\hline 43 & Tetrahydrofuran & 2.05 & - & - & - & - & - & - & - & - & - & - & - & - & - & - & - & - \\
\hline 44 & 1,4-Dioxane & 2.82 & - & - & - & - & - & - & - & - & - & - & - & - & - & - & - & - \\
\hline 45 & Methyl methacrylate & 2.86 & - & - & - & - & - & - & - & - & - & - & - & - & - & - & - & - \\
\hline 46 & Ethyl methacrylate & 4.41 & - & - & - & - & - & - & - & - & - & - & - & - & - & - & - & - \\
\hline \multicolumn{19}{|c|}{ Aromatic hydrocarbons } \\
\hline 47 & Benzene & 2.31 & 2.9 & 1.0 & 0.43 & 2.4 & 0.47 & 0.54 & 2.6 & 0.079 & 1.5 & 0.9 & 3.6 & 5.9 & 2.3 & 0.93 & 5.1 & 3.2 \\
\hline 48 & Toluene & 3.90 & 1.1 & 0.37 & 0.074 & 0.62 & 0.31 & 0.11 & 3.1 & 1.6 & 1.6 & 0.29 & 1.8 & 1.3 & 1.1 & 0.24 & 1.9 & 1.8 \\
\hline 49 & Ethylbenzene & 6.89 & 0.14 & 0.084 & 0.004 & 0.14 & 0.018 & 0.180 & 0.34 & 0.16 & 8.2 & 0.19 & 1.6 & 0.24 & 0.79 & 0.030 & 0.19 & 0.18 \\
\hline 50,51 & M,p-Xylene & 7.20 & 0.30 & 0.090 & 0.008 & 0.22 & 0.028 & 0.43 & 0.8 & 0.24 & 18 & 0.25 & 2.3 & 0.48 & 1.4 & 0.025 & 0.28 & 0.38 \\
\hline 52 & Styrene & 7.93 & 0.13 & 0.026 & 0.011 & 0.20 & 0.062 & 0.022 & 0.38 & 0.13 & 0.76 & 0.032 & 0.20 & 0.10 & 0.17 & 0.006 & 0.11 & 0.12 \\
\hline 53 & o-Xylene & 7.96 & 0.49 & 0.060 & 0.017 & 0.19 & 0.040 & 0.77 & 0.42 & 0.092 & 30 & 0.26 & 1.9 & 0.22 & 1.2 & 0.038 & 0.20 & 0.17 \\
\hline 54 & Isopropylbenzene & 9.01 & 0.023 & 0.005 & 0.002 & 0.011 & 0.003 & 0.021 & 0.037 & 0.011 & 1.2 & 0.019 & 0.18 & 0.011 & 0.12 & 0.004 & 0.030 & 0.014 \\
\hline 55 & n-Propylbenzene & 10.00 & 0.036 & 0.011 & $<0.002$ & 0.025 & 0.008 & 0.004 & 0.15 & 0.038 & 0.11 & 0.027 & 0.28 & 0.078 & 0.22 & 0.005 & 0.10 & 0.060 \\
\hline 56 & 1,3,5-Trimethylbenzene & 10.51 & 0.006 & 0.007 & $<0.004$ & 0.039 & 0.006 & 0.013 & 0.024 & 0.007 & 0.26 & 0.017 & 0.23 & 0.031 & 0.21 & - & 0.035 & 0.004 \\
\hline 57 & tert-Butylbenzene & 11.18 & - & - & - & - & - & - & 0.006 & 0.004 & - & - & - & 0.004 & - & - & 0.029 & - \\
\hline 58 & 1,2,4-Trimethylbenzene & 11.26 & 0.015 & 0.021 & $<0.007$ & 0.054 & 0.009 & 0.011 & 0.056 & 0.046 & 0.70 & 0.11 & 1.5 & 0.065 & 2.0 & $<0.007$ & 0.27 & 0.011 \\
\hline 59 & sec-Butylbenzene & 11.73 & 0.002 & 0.001 & - & 0.005 & 0.001 & 0.001 & 0.011 & 0.004 & 0.064 & 0.010 & 0.11 & 0.008 & 0.12 & $<0.004$ & 0.016 & 0.002 \\
\hline \multicolumn{19}{|c|}{ Halogenated aromatic hydrocarbons } \\
\hline 62 & Chlorobenzene & 6.35 & 0.036 & 0.004 & $<0.004$ & 0.10 & 0.042 & $<0.004$ & 0.080 & 0.075 & 0.10 & $<0.004$ & 0.036 & 0.068 & 0.008 & - & 0.020 & 0.023 \\
\hline 63 & Bromobenzene & 9.2 & - & - & - & $<0.007$ & $<0.007$ & - & $<0.007$ & $<0.007$ & $<0.007$ & - & $<0.007$ & $<0.007$ & $<0.007$ & $<0.007$ & $<0.007$ & $<0.007$ \\
\hline 64 & 2-Chlorotoluene & 9.86 & - & - & - & - & - & - & - & - & - & - & - & - & - & - & - & - \\
\hline 65 & 4-Chlorotoluene & 10.12 & - & - & - & - & - & - & - & - & - & - & - & - & - & - & - & - \\
\hline 66 & 1,3-Dichlorobenzene & 11.58 & - & - & - & 0.029 & 0.010 & - & 0.022 & $<0.008$ & 0.015 & - & $<0.008$ & 0.011 & - & - & - & $<0.008$ \\
\hline 67 & 1,4-Dichlorobenzene & 11.87 & $<0.008$ & $<0.008$ & $<0.008$ & 0.021 & $<0.008$ & $<0.008$ & 0.025 & $<0.008$ & 0.027 & $<0.008$ & 0.009 & $<0.008$ & 0.083 & $<0.008$ & $<0.008$ & $<0.008$ \\
\hline 68 & 1,2-Dichlorobenzene & 12.38 & - & $<0.005$ & $<0.005$ & 0.011 & 0.005 & $<0.005$ & 0.012 & $<0.005$ & 0.096 & $<0.005$ & 0.007 & $<0.005$ & $<0.005$ & $<0.005$ & - & - \\
\hline 69 & 1,2-Dibromo-3-chloropropane & 13.98 & - & - & - & - & - & - & - & - & - & - & & & & - & - & - \\
\hline 70 & 1,2,4-Trichlorobenzene & 16.31 & - & $<0.002$ & $<0.002$ & 0.012 & 0.002 & $<0.002$ & 0.009 & - & 0.022 & $<0.002$ & 0.003 & 0.003 & $<0.002$ & $<0.002$ & - & - \\
\hline 71 & $1,2,3$-Trichlorobenzene & 17.11 & - & - & - & 0.009 & 0.002 & - & 0.010 & 0.002 & 0.004 & - & 0.002 & 0.006 & $<0.002$ & - & $<0.002$ & $<0.002$ \\
\hline
\end{tabular}


Surprisingly, not a single priority VOC with $\mathrm{O}, \mathrm{N}$, or $\mathrm{S}$ atoms was detected in any of the collected samples (Table 1).

As expected, aromatic hydrocarbons were mainly represented by BTEX group: Benzene $\left(0.08-5.9 \mu \mathrm{g} / \mathrm{m}^{3}\right)$, toluene $\left(0.07-3.1 \mu \mathrm{g} / \mathrm{m}^{3}\right)$, ethylbenzene $\left(0-8.2 \mu \mathrm{g} / \mathrm{m}^{3}\right)$, as well as xylenes with typical concentrations of tenths of $\mu \mathrm{g} / \mathrm{m}^{3}$. The exception involved point 9 , where the concentration of $o$-xylene reached 30, and the sum of $m$ - and $p$-xylenes was $18 \mu \mathrm{g} / \mathrm{m}^{3}$ or $48 \mu \mathrm{g} / \mathrm{m}^{3}$ for the sum of them. The safe level of xylenes in the air is $300 \mu \mathrm{g} / \mathrm{m}^{3}$ [27], i.e., the highest detected concentration constituted $15 \%$ of the safe level. Point 9, like points 7 and 8 , is located in the zone of active oil and gas production in the North-Western Siberia and the adjacent shelf, which, apparently, is the main source of hydrocarbons emission to the atmosphere. Another local source of BTEX is maritime transport (incomplete fuel combustion) serving oil companies. The safe level of ethylbenzene is $20 \mu \mathrm{g} / \mathrm{m}^{3}$ [27], i.e., concentration of that compound at point 9 was $\sim 40 \%$ of that value.

Halogenated aromatic hydrocarbons are mainly represented by chlorobenzene with a concentration that reached a maximum of $0.1 \mu \mathrm{g} / \mathrm{m}^{3}$ at the sampling point 4 , as well as at already mentioned points 7-9. This compound is widely used as a high-boiling solvent in many industrial applications and can enter the atmosphere directly as a result of the activities of oil and gas enterprises and port facilities, as well as due to volatilization from the waters of large rivers flowing through the industrial centers of Siberia.

\subsection{Semi-Volatile Organic Compounds}

The SVOCs found in the studied air samples (Table 2) can be conditionally divided into five groups: $\mathrm{CHO}$-compounds, $\mathrm{N}$-containing compounds, halogenated compounds, polycyclic aromatic hydrocarbons (PAHs), and phthalic acid esters (phthalates).

Figure 4 clearly shows that the first group of compounds predominated and accounted for up to $90-99 \%$ of the total mass of target analytes.

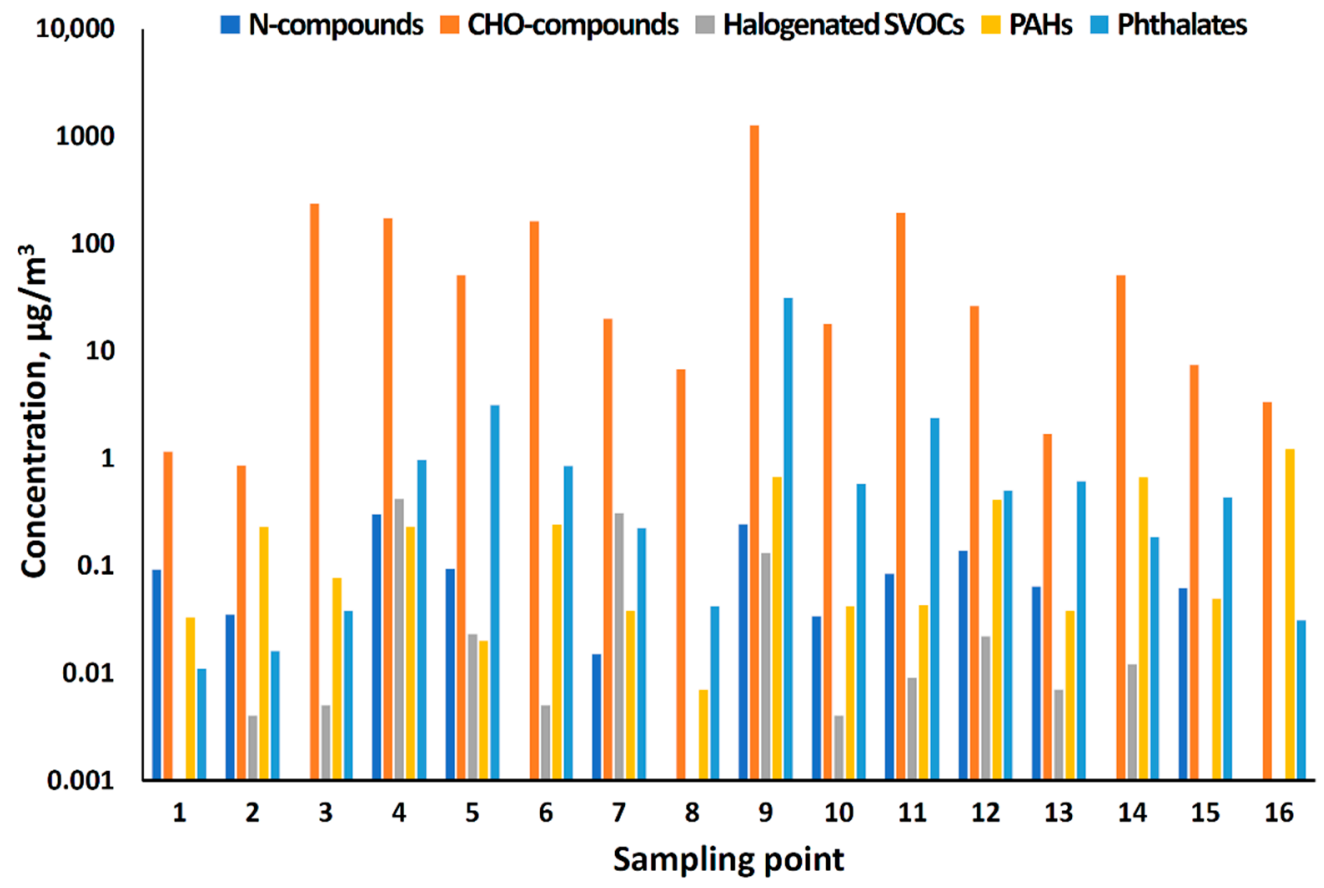

Figure 4. The sum concentrations of SVOC groups in the studied air samples. 
Table 2. Concentrations of semi-volatile organic compounds in the air samples measured by TD-GC-HRMS.

\begin{tabular}{|c|c|c|c|c|c|c|c|c|c|c|c|c|c|c|c|c|c|c|}
\hline \multirow{2}{*}{ Number } & \multirow{2}{*}{ Compounds } & \multirow{2}{*}{$\begin{array}{c}\text { Tr, } \\
\text { min }\end{array}$} & \multicolumn{16}{|c|}{ Concentration, $\mu \mathrm{g} / \mathrm{m}^{3}$, at Sampling Point } \\
\hline & & & 1 & 2 & 3 & 4 & 5 & 6 & 7 & 8 & 9 & 10 & 11 & 12 & 13 & 14 & 15 & 16 \\
\hline \multicolumn{19}{|c|}{$\mathrm{N}$-compounds } \\
\hline 72 & N-Nitrosodimethylamine & 3.35 & - & - & - & - & & - & - & - & - & & - & - & - & - & & - \\
\hline 74 & Aniline & 10.72 & - & - & - & - & - & - & - & - & - & - & - & - & - & - & - & - \\
\hline 75 & N-Nitroso-di-n-propylamine & 13.50 & - & - & - & - & - & - & - & - & - & - & - & - & - & - & - & - \\
\hline 76 & 2-Nitrophenol & 15.12 & - & - & - & - & - & - & - & - & - & - & - & - & - & - & - & - \\
\hline 77 & 4-Chloroaniline & 16.95 & - & $<0.033$ & - & $<0.033$ & $<0.033$ & - & - & - & - & $<0.033$ & $<0.033$ & - & $<0.033$ & $<0.033$ & - & - \\
\hline 78 & 2-Nitroaniline & 21.58 & - & $<0.035$ & $<0.035$ & 0.042 & $<0.035$ & $<0.035$ & $<0.035$ & - & $<0.035$ & $<0.035$ & $<0.035$ & - & $<0.035$ & $<0.035$ & - & - \\
\hline 79 & 1,4-Dinitrobenzene & 22.17 & - & - & - & $<0.074$ & & - & - & - & - & - & - & - & - & - & - & - \\
\hline 81 & 2,6-Dinitrotoluene & 22.62 & - & - & - & - & - & - & - & - & - & - & - & - & - & - & - & - \\
\hline 82 & 1,2 -Dinitrobenzene & 22.74 & - & - & - & - & - & - & - & - & - & - & - & - & - & - & - & - \\
\hline 83 & 3-Nitroaniline & 23.20 & - & - & - & - & - & - & - & - & - & - & - & - & - & - & - & - \\
\hline 84 & 2,4-Dinitrophenol & 23.62 & - & - & - & - & - & - & - & - & - & - & - & - & - & - & - & - \\
\hline 85 & 2,4-Dinitrotoluene & 24.13 & - & - & - & 0.015 & - & - & - & - & - & - & - & - & - & - & - & - \\
\hline 86 & 4-Nitroaniline & 25.55 & - & - & - & - & - & - & - & - & - & - & - & - & - & - & - & - \\
\hline 87 & 4,6-Dinitro-2-methylphenol & 25.67 & - & - & - & - & - & - & - & - & - & - & - & - & - & - & - & - \\
\hline 88 & Diphenylamine & 25.97 & - & - & - & 0.022 & - & - & - & - & - & - & - & - & - & - & - & - \\
\hline 89 & Azobenzene & 26.05 & - & - & - & - & -1 & - & - & - & 0.023 & $<0.005$ & - & $<0.005$ & - & $<0.005$ & $<0.005$ & $<0.005$ \\
\hline 90 & Carbazole & 29.88 & - & - & - & 0.017 & $<0.017$ & $<0.017$ & $<0.017$ & - & $<0.017$ & $<0.017$ & $<0.017$ & $<0.017$ & $<0.017$ & $<0.017$ & - & $<0.017$ \\
\hline \multicolumn{19}{|c|}{ CHO-compounds } \\
\hline 93 & 2-Methylphenol & 13.05 & - & - & - & 0.072 & - & - & - & - & 0.020 & - & 0.013 & 0.030 & 0.018 & - & 0.014 & - \\
\hline 94,95 & 3- and 4-Methylphenol & 13.5 & - & 0.16 & 0.060 & 0.58 & 0.15 & 0.064 & - & - & 0.88 & 0.069 & 0.18 & 0.070 & 0.21 & 0.043 & 0.041 & - \\
\hline 96 & 2,4-Dimethylphenol & 15.6 & - & $<0.033$ & - & 0.038 & & - & - & - & 0.038 & . & $<0.033$ & - & $<0.033$ & - & & - \\
\hline 97 & Benzoic acid & 16.23 & 1.2 & - & 235 & 165 & 49 & 161 & 20 & 6.7 & 1222 & 17 & 191 & 24 & 0.53 & 50 & 7.0 & 3.3 \\
\hline 98 & Isophorone & 14.87 & $<0.002$ & $<0.002$ & $<0.002$ & $<0.002$ & $<0.002$ & $<0.002$ & $<0.002$ & $<0.002$ & $<0.002$ & $<0.002$ & $<0.002$ & $<0.002$ & $<0.002$ & $<0.002$ & $<0.002$ & $<0.002$ \\
\hline \multicolumn{19}{|c|}{ Halogenated SVOCs } \\
\hline 99 & 2-Chlorophenol & 11.07 & - & - & $<0.008$ & 0.086 & 0.020 & - & - & - & 0.008 & - & $<0.008$ & 0.022 & $<0.008$ & - & - & - \\
\hline 100 & 2,4-Dichlorophenol & 16.07 & - & - & - & 0.054 & - & - & 0.059 & $<0.033$ & $<0.033$ & - & $<0.033$ & $<0.033$ & $<0.033$ & $<0.033$ & - & - \\
\hline 101 & 4-Chloro-3-methylphenol & 19.03 & - & - & - & 0.036 & - & - & - & - & $<0.025$ & - & $<0.025$ & - & $<0.025$ & $<0.025$ & - & - \\
\hline 102 & 2,4,6-Trichlorophenol & 20.43 & - & - & - & 0.059 & - & - & 0.040 & $<0.010$ & 0.021 & - & $<0.010$ & $<0.010$ & $<0.010$ & $<0.010$ & $<0.010$ & $<0.010$ \\
\hline 103 & 2,4,5-Trichlorophenol & 20.53 & - & - & - & 0.057 & - & - & 0.059 & $<0.013$ & 0.023 & $<0.013$ & $<0.013$ & $<0.013$ & - & $<0.013$ & - & $<0.013$ \\
\hline 104 & 2,3,5,6-Tetrachlorophenol & 24.39 & - & - & - & 0.044 & - & - & 0.062 & - & 0.037 & - & - & $<0.033$ & - & - & - & $<0.033$ \\
\hline 105 & 2,3,4,6-Tetrachlorophenol & 24.55 & - & - & - & 0.047 & - & - & 0.066 & $<0.025$ & 0.033 & - & $<0.025$ & $<0.025$ & - & - & - & $<0.025$ \\
\hline 106 & 4-Chlorophenyl phenyl ether & 25.49 & - & - & - & - & - & - & - & - & - & - & - & - & - & - & - & - \\
\hline 107 & Pentachlorophenol & 28.19 & - & - & - & - & - & - & $<0.21$ & - & $<0.21$ & - & - & - & - & - & - & - \\
\hline 108 & Bis(2-chloroethyl)ether & 11.07 & - & - & - & - & - & - & - & - & - & - & - & - & - & - & - & - \\
\hline 109 & Hexachloroethane & 13.57 & - & 0.004 & 0.005 & 0.007 & 0.003 & 0.005 & - & - & 0.009 & 0.004 & 0.006 & - & 0.005 & 0.005 & - & - \\
\hline 110 & Bis(2-chloroethoxy)methane & 15.92 & - & - & - & - & & - & - & - & - & - & - & - & - & - & - & - \\
\hline 111 & Hexachlorocyclopentadiene & 19.91 & - & - & - & - & - & - & - & - & - & - & - & - & - & - & - & - \\
\hline 112 & 2-Chloronaphthalene & 21.02 & - & - & - & 0.016 & $<0.002$ & - & 0.005 & - & $<0.002$ & - & 0.003 & - & 0.002 & 0.002 & - & - \\
\hline 113 & Hexachlorobenzene & 27.35 & - & - & - & 0.012 & & - & 0.017 & - & $<0.005$ & $<0.005$ & $<0.005$ & - & $<0.005$ & 0.005 & - & - \\
\hline 114 & 4-Bromophenyl phenyl ether & 27.33 & - & - & - & - & - & - & - & - & - & - & - & - & - & - & - & - \\
\hline \multicolumn{19}{|c|}{ Polycyclic aromatic hydrocarbons } \\
\hline
\end{tabular}


Table 2. Cont.

\begin{tabular}{|c|c|c|c|c|c|c|c|c|c|c|c|c|c|c|c|c|c|c|}
\hline \multirow{2}{*}{ Number } & \multirow{2}{*}{ Compounds } & \multirow{2}{*}{$\begin{array}{c}\operatorname{Tr}_{\text {, }} \\
\text { min }\end{array}$} & \multicolumn{16}{|c|}{ Concentration, $\mu \mathrm{g} / \mathrm{m}^{3}$, at Sampling Point } \\
\hline & & & 1 & 2 & 3 & 4 & 5 & 6 & 7 & 8 & 9 & 10 & 11 & 12 & 13 & 14 & 15 & 16 \\
\hline 115 & Naphthalene & 16.51 & 0.025 & 0.12 & 0.051 & 0.11 & 0.012 & 0.058 & 0.025 & 0.004 & 0.10 & 0.011 & 0.008 & 0.18 & 0.013 & 0.20 & 0.010 & 0.30 \\
\hline 116 & 2-Methylnaphthalene & 19.21 & 0.004 & 0.029 & 0.014 & 0.046 & 0.003 & 0.11 & 0.003 & - & 0.034 & $<0.002$ & - & 0.026 & 0.007 & 0.16 & $<0.002$ & 0.42 \\
\hline 117 & 1-Methylnaphthalene & 19.56 & 0.004 & 0.025 & 0.012 & 0.039 & 0.003 & 0.070 & 0.003 & - & 0.031 & $<0.002$ & - & 0.016 & 0.005 & 0.11 & 0.002 & 0.28 \\
\hline 118 & Acenaphthylene & 22.55 & - & 0.005 & - & - & - & - & $<0.002$ & - & 0.029 & 0.002 & - & 0.005 & $<0.002$ & 0.004 & 0.003 & 0.007 \\
\hline 119 & Acenaphthene & 23.26 & - & 0.004 & - & - & - & 0.002 & $<0.002$ & - & 0.007 & $<0.002$ & - & 0.004 & $<0.002$ & 0.007 & 0.002 & 0.009 \\
\hline 120 & Dibenzofuran & 23.94 & - & 0.015 & $<0.002$ & 0.008 & 0.002 & 0.002 & 0.004 & 0.003 & 0.092 & 0.009 & 0.004 & 0.056 & 0.008 & 0.048 & 0.011 & 0.040 \\
\hline 121 & Fluorene & 25.25 & - & 0.005 & - & 0.005 & & 0.004 & 0.003 & $<0.002$ & 0.009 & 0.003 & $<0.002$ & 0.010 & 0.002 & 0.017 & 0.003 & 0.018 \\
\hline 122 & Phenanthrene & 28.86 & - & $<0.022$ & - & 0.022 & $<0.022$ & $<0.022$ & $<0.022$ & $<0.022$ & 0.10 & $<0.022$ & $<0.022$ & 0.068 & $<0.022$ & 0.078 & $<0.022$ & 0.10 \\
\hline 123 & $\begin{array}{l}\text { Anthracene } \\
\text { Shen }\end{array}$ & 29.06 & - & - & - & - & $<0.007$ & - & $<0.007$ & $<0.007$ & 0.039 & $<0.007$ & 0.031 & 0.009 & $<0.007$ & 0.010 & $<0.007$ & 0.013 \\
\hline 124 & Fluoranthene & 33.45 & - & 0.010 & - & $<0.004$ & - & - & $<0.004$ & $<0.004$ & 0.078 & 0.008 & $<0.004$ & 0.018 & 0.003 & 0.012 & 0.009 & 0.014 \\
\hline 125 & Pyrene & 34.26 & - & 0.013 & - & 0.003 & - & - & $<0.004$ & $<0.004$ & 0.069 & 0.010 & $<0.004$ & 0.017 & $<0.004$ & 0.014 & 0.009 & 0.022 \\
\hline 126 & Benz(a)anthracene & 38.98 & - & - & - & - & - & - & $<0.033$ & $<0.033$ & 0.033 & $<0.033$ & $<0.033$ & $<0.033$ & $<0.033$ & $<0.033$ & $<0.033$ & $<0.033$ \\
\hline 127 & Chrysene & 39.1 & - & - & - & - & - & - & $<0.025$ & $<0.025$ & 0.051 & $<0.025$ & $<0.025$ & $<0.025$ & $<0.025$ & $<0.025$ & $<0.025$ & $<0.025$ \\
\hline 128 & Benzo[b]fluoranthene & 42.94 & - & - & - & - & - & - & - & - & - & - & - & - & - & - & - & - \\
\hline 129 & Benzo[k]fluoranthene & 43.03 & - & - & - & - & - & - & - & - & - & - & - & - & - & - & - & - \\
\hline 130 & Benzo[a]pyrene & 43.93 & - & - & - & - & - & - & - & - & - & - & - & - & - & - & - & - \\
\hline 131 & Benzo[g,h,i] perylene & 48.27 & - & - & - & - & - & - & - & - & - & - & - & - & - & - & - & - \\
\hline \multicolumn{19}{|c|}{ Phthalates } \\
\hline 132 & Dimethylphthalate & 22.51 & - & - & - & 0.030 & $<0.004$ & $<0.004$ & - & - & 0.015 & - & 0.009 & - & 0.008 & $<0.004$ & - & - \\
\hline 133 & Diethylphthalate & 25.31 & - & - & 0.012 & 0.11 & 0.007 & 0.012 & 0.13 & 0.026 & 0.066 & - & 0.077 & 0.46 & 0.014 & 0.002 & 0.007 & - \\
\hline 134 & Di-n-butyl phthalate & 31.76 & - & - & 0.008 & 0.22 & 0.024 & 0.031 & - & - & 2.0 & 0.010 & 0.82 & - & 0.026 & 0.008 & - & - \\
\hline 135 & Benzyl butyl phthalate & 37.5 & - & - & - & 0.009 & $<0.004$ & $<0.004$ & $<0.004$ & - & 0.25 & - & 0.005 & - & $<0.004$ & $<0.004$ & - & - \\
\hline 138 & Di-n-octyl phthalate & 42.42 & & - & - & - & - & - & - & - & - & - & - & - & - & - & - & - \\
\hline
\end{tabular}


As noted above (Section 3.1), benzoic acid was the dominant compound not only inside the $\mathrm{CHO}$ group, but also among all detected SVOCs. Typically, its concentration ranged from $0.5 \mu \mathrm{g} / \mathrm{m}^{3}$ to several tens $\mu \mathrm{g} / \mathrm{m}^{3}$. In sample 9, it reached an extreme level of $1200 \mu \mathrm{g} / \mathrm{m}^{3}$, nicely correlating with the high content of aromatic hydrocarbons in it.

A significant amount of benzoic acid in the atmospheric air and precipitations was detected earlier in the western sector of the Arctic, on the islands of Novaya Zemlya [22,35] and Franz Josef Land [23,35], as well as in much lower concentrations in atmospheric aerosols in the territory of the Svalbard archipelago and Greenland [36]. The main source of benzoic acid in the atmosphere involves biomass burning [37], of which it is the most important marker. Benzoic acid can be also formed in the atmosphere due to the oxidation of aromatic hydrocarbons or their monosubstituted derivatives.

The other major compounds of CHO-group were also products of biomass combustion. They were represented by phenol $\left(0.58-6.0 \mu \mathrm{g} / \mathrm{m}^{3}\right)$ and its methyl derivatives, mostly $m$, $p$-cresols $\left(0.04-0.9 \mu \mathrm{g} / \mathrm{m}^{3}\right)$. Benzyl alcohol was also found in the concentration range from 0.02 to $37 \mu \mathrm{g} / \mathrm{m}^{3}$. The safe level of phenol is $10 \mu \mathrm{g} / \mathrm{m}^{3}$ [27], i.e., the concentration of that compound at point 9 was $\sim 60 \%$ of that value, meaning that it requires special attention.

The vast majority of the target nitrogen-containing compounds were not detected in the studied air samples. The exception involves pyridine, which is a toxic substance and is included in the list of priority pollutants. At a level above the LOQ, it was detected in ten samples, and its concentrations varied from 0.010 to $0.221 \mu \mathrm{g} / \mathrm{m}^{3}$. As noted in the Introduction, earlier pyridine was found in the snow sampled from the Novaya Zemlya archipelago in amounts of $0.100-1 \mu \mathrm{g} / \mathrm{kg}$ [22], in Moscow rain [38] and snow [39], and in cloud water in Central France [40]. Pyridine and its alkylated derivatives require more attention and can be considered a product of incomplete combustion (smoldering) of peat [11].

Phthalates are the constituents of various industrial products being produced in the volume over 470 million pounds per year (EPA 2006) [41]. Phthalates represent a special environmental concern as endocrine-disrupting chemicals (EDGCs) [42]. Earlier, we reported the presence of phthalates in rather high levels in the snow sampled from the Novaya Zemlya archipelago [22], in Moscow rain [38] and snow [39,43], and in cloud water in Central France [40]. Phthalates were also found in noticeable quantities in the present Arctic air samples occupying the second or third place in terms of total content (Figure 4). It reached units of $\mu \mathrm{g} / \mathrm{m}^{3}$, and in sample 9, the concentration was $31 \mu \mathrm{g} / \mathrm{m}^{3}$. The most common representatives of this class of pollutants were bis-(2-ethylhexyl) phthalate, di- $n$-butyl phthalate, and diethyl phthalate.

Polycyclic aromatic hydrocarbons, with the exception of the six most hardly volatile compounds, like other products of fuel combustion, were found in the majority of the collected air samples in concentrations comparable to phthalates (Figure 4, Table 2). Naphthalene and its methylated derivatives were detected in the highest concentration among the representatives of that group. It is also worth mentioning that, similarly to the precipitation samples from various sites from the Arctic to the tropics [22,39,40,43-45], fluoranthene and chrysene levels were higher than that of other detected $\mathrm{PAH}$, except naphthalene (Table 2). A feature of PAHs in the Arctic air samples involved the presence of a number of peaks of isomeric ions with higher retention times and relatively high intensities on XIC chromatograms (Figure 2). Based on their elemental compositions, they could be classified as fragment ions of PAH oxygenates formed in the atmosphere during the oxidation of the parent PAHs. The identification of these compounds is beyond the scope of this work, being the subject of a future study.

The last SVOC group, which includes halogenated compounds, was mainly represented by 2-chlorophenol, as well as some other chlorophenols in trace concentrations. The sources of those priority pollutants with high toxicity involve waste waters from the pulp and paper industry, water disinfection, antiseptic compositions, and plant protection agents. The release of chlorophenols into the atmosphere is also possible due to evaporation 
from seawater, as their content in the western Arctic seawater was estimated recently at a level of several ng/L [46].

\section{Conclusions}

The first reliable dataset so far dealing with the levels of volatile and semi volatile organic priority pollutants was obtained in terms of the International Siberian Shelf Study Expedition (ISSS-2020) project with the research vessel Akademik Keldysh in 2020 in the White, Barents, Kara, East Siberian, and Laptev Seas and following analysis with TD-GC-HRMS. Eighty-six out of 138 pollutants were detected and quantified. Although the concentrations of the majority of them were several orders of magnitude below the established safe levels, xylenes, ethylbenzene, and phenol require special attention in the future, demonstrating levels of $15 \%, 40 \%$, and $60 \%$ of the safe values, respectively. The principal source of organic compounds in the Arctic air involves biomass burning, while sea plants and water contaminants may be responsible for the presence of certain brominated and chlorinated species. However, a deeper investigation based on modelling/backtrajectory analysis to identify the sources of the detected compounds is in our plans for the near future. The corresponding expeditions with our participation are planned for 2021 and 2022.

Supplementary Materials: The following are available online at https:/ /www.mdpi.com/article/10 .3390 /atmos12060767/s1, Table S1: Coordinates of sampling points, atmospheric conditions, and dates of air collection, Table S2: Target VOCs, corresponding quantifier ions, and limits of detection and quantification, Table S3: Target SVOCs, corresponding quantifier ions, and limits of detection and quantification. Figures S1-S16: Reconstructed XIC chromatograms of the target analytes in air samples No. 1-16.

Author Contributions: Conceptualization, D.S.K. and A.T.L.; methodology, D.S.K. and N.V.U.; validation, I.S.S. and N.V.U.; formal analysis, I.S.S., D.S.K., and N.V.U.; investigation, I.S.S. and D.E.L.; data curation, I.S.S., D.E.L., and N.V.U.; writing-original draft preparation, I.S.S. and N.V.U.; writing-review and editing, D.S.K. and A.T.L.; visualization, I.S.S. and N.V.U.; supervision, A.T.L.; project administration, D.S.K. and A.T.L.; funding acquisition, D.S.K. All authors have read and agreed to the published version of the manuscript.

Funding: This research was funded by the Ministry of Science and Higher Education of the Russian Federation, state assignment project number 0793-2020-0007.

Institutional Review Board Statement: Not applicable.

Informed Consent Statement: Not applicable.

Data Availability Statement: The data presented in this study are available in the article and supplementary material.

Acknowledgments: This study was performed using an instrumentation of the Core Facility Center "Arktika" of the Northern (Arctic) Federal University. We would like to thank Aleksandr Kozhevnikov and Igor Semiletov for organizing expeditionary work.

Conflicts of Interest: The authors declare no conflict of interest. The funders had no role in the design of the study; in the collection, analyses, or interpretation of data; in the writing of the manuscript, or in the decision to publish the results.

\section{References}

1. Cressey, D. Scientific challenges in the Arctic: Open water. Nature 2011, 478, 174-177. [CrossRef]

2. $\quad$ Law, K.S.; Roiger, A.; Thomas, J.L.; Marelle, L.; Raut, J.C.; Dalsøren, S.; Fuglestvedt, J.; Tuccella, P.; Weinzierl, B.; Schlager, H. Local Arctic air pollution: Sources and impacts. Ambio 2017, 46, 453-463. [CrossRef]

3. Law, K.S.; Stohl, A. Arctic Air Pollution: Origins and Impacts. Science 2007, 315, 1537-1540. [CrossRef]

4. Kallenborn, R.; Hung, H.; Brorström-Lundén, E. Atmospheric Long-Range Transport of Persistent Organic Pollutants (POPs) into Polar Regions. Compr. Anal. Chem. 2015, 67, 411-432. [CrossRef] 
5. Ma, J.; Hung, H.; Macdonald, R.W. The influence of global climate change on the environmental fate of persistent organic pollutants: A review with emphasis on the Northern Hemisphere and the Arctic as a receptor. Glob. Planet. Change 2016, 146, 89-108. [CrossRef]

6. Poliakova, O.V.; Lebedev, A.T.; Hanninen, O. Organic pollutants in snow of urban and rural Russia and Finland. Toxicol. Environ. Chem. 2000, 75, 181-194. [CrossRef]

7. Lindwall, F.; Svendsen, S.S.; Nielsen, C.S.; Michelsena, A.; Rinnan, R. Warming increases isoprene emissions from an arctic fen. Sci. Total Environ. 2016, 553, 297-304. [CrossRef]

8. Svendsen, S.S.; Lindwall, F.; Michelsena, A.; Rinnan, R. Biogenic volatile organic compound emissions along a high arctic soil moisture gradient. Sci. Total Environ. 2016, 573, 131-138. [CrossRef]

9. Choi, J.H.; Jang, E.; Yoon, Y.J.; Park, J.Y.; Kim, T.-W.; Becagli, S.; Caiazzo, L.; Cappelletti, D.; Krejci, R.; Eleftheriadis, K.; et al. Influence of Biogenic Organics on the Chemical Composition of Arctic Aerosols. Glob. Biogeochem. Cycles. 2019, 33, 1238-1250. [CrossRef]

10. Blake, D.; Hinwood, A.L.; Horwitz, P. Peat fires and air quality: Volatile organic compounds and particulates. Chemosphere 2009, 76, 419-423. [CrossRef] [PubMed]

11. Kosyakov, D.S.; Ul'yanovskii, N.V.; Latkin, T.B.; Pokryshkin, S.A.; Berzhonskis, V.R.; Polyakova, O.V.; Lebedev, A.T. Peat burning-An important source of pyridines in the earth atmosphere. Environ. Pollut. 2020, 266, 115109. [CrossRef]

12. Feltracco, M.; Barbaro, E.; Tedeschi, S.; Spolaor, A.; Turetta, C.; Vecchiato, M.; Morabito, E.; Zangrando, R.; Barbante, C.; Gambaro, A. Interannual variability of sugars in Arctic aerosol: Biomass burning and biogenic inputs. Sci. Total Environ. 2020, 706, 136089. [CrossRef]

13. Newland, M.J.; Martinerie, P.; Witrant, E.; Helmig, D.; Worton, D.R.; Hogan, C.; Sturges, W.T.; Reeves, C.E. Changes to the chemical state of the Northern Hemisphere atmosphere during the second half of the twentieth century. Atmos. Chem. Phys. 2017, 17, 8269-8283. [CrossRef]

14. Arnold, S.R.; Law, K.S.; Brock, C.A.; Thomas, J.L.; Starkweather, S.M.; Von Salzen, K.; Stohl, A.; Sharma, S.; Lund, M.T.; Flanner, M.G.; et al. Arctic air pollution: Challenges and opportunities for the next decade. Elem. Sci. Anthr. 2016, 4, 000104. [CrossRef]

15. AMAP. Assessment 2015: Temporal Trends in Persistent Organic Pollutants in the Arctic. In Arctic Monitoring and Assessment Programme; AMAP: Oslo, Norway, 2016; 71p.

16. Wong, F.; Hung, H.; Dryfhout-Clark, H.; Aas, W.; Bohlin-Nizzetto, P.; Breivik, K.; Mastromonaco, M.N.; Lundén, E.B.; Ólafsdóttir, K.; Sigurðsson, Á.; et al. Time trends of persistent organic pollutants (POPs) and Chemicals of Emerging Arctic Concern (CEAC) in Arctic air from 25 years of monitoring. Sci. Total Environ. 2021, 775, 145109. [CrossRef] [PubMed]

17. Butt, C.M.; Berger, U.; Bossi, R.; Tomy, G.T. Levels and trends of poly- and perfluorinated compounds in the arctic environment. Sci. Total Environ. 2010, 408, 2936-2965. [CrossRef]

18. Yu, Y.; Katsoyiannis, A.; Bohlin-Nizzetto, P.; Brorström-Lundén, E.; Ma, J.; Zhao, Y.; Wu, Z.; Tych, W.; Mindham, D.; Sverko, E.; et al. Polycyclic Aromatic Hydrocarbons Not Declining in Arctic Air Despite Global Emission Reduction. Environ. Sci. Technol. 2019, 53, 2375-2382. [CrossRef]

19. Pernov, J.B.; Bossi, R.; Lebourgeois, T.; Nøjgaard, J.K.; Holzinger, R.; Hjorth, J.L.; Skov, H. Atmospheric VOC measurements at a High Arctic site: Characteristics and source apportionment. Atmos. Chem. Phys. 2021, 21, 2895-2916. [CrossRef]

20. Röhler, L.; Schlabach, M.; Haglund, P.; Breivik, K.; Kallenborn, R.; Bohlin-Nizzetto, P. Non-target and suspect characterisation of organic contaminants in Arctic air-Part 2: Application of a new tool for identification and prioritisation of chemicals of emerging Arctic concern in air. Atmos. Chem. Phys. 2020, 20, 9031-9049. [CrossRef]

21. Kos, G.; Kanthasami, V.; Adechina, N.; Ariya, P.A. Volatile organic compounds in Arctic snow: Concentrations and implications for atmospheric processes. Environ. Sci. Process. Impacts 2014, 16, 2592-2603. [CrossRef] [PubMed]

22. Lebedev, A.T.; Mazur, D.M.; Polyakova, O.V.; Kosyakov, D.S.; Kozhevnikov, A.Y.; Latkin, T.B.; Andreeva, Y.I.; Artaev, V.B. Semi volatile organic compounds in the snow of Russian Arctic islands: Archipelago Novaya Zemlya. Environ. Pollut. 2018, 239, 416-427. [CrossRef]

23. Mazur, D.M.; Latkin, T.B.; Kosyakov, D.S.; Kozhevnikov, A.Y.; Ul'yanovskii, N.V.; Kirilov, A.G.; Lebedev, A.T. Arctic snow pollution: A GC-HRMS case study of Franz Joseph Land archipelago. Environ. Pollut. 2020, 265, 114885. [CrossRef] [PubMed]

24. Method 8260D Volatile Organic Compounds by Gas Chromatography/Mass Spectrometry (GC/MS); Revision 4; US Environmental Protection Agency: Washington, DC, USA, 2018.

25. Method 8270E Semivolatile Organic Compounds by Gas Chromatography/Mass Spectrometry (GC/MS); Revision 6; US Environmental Protection Agency: Washington, DC, USA, 2018.

26. Zaikin, V.; Halket, J. A Handbook of Derivatives for Mass Spectrometry; IM Publications LLP: Chichester, UK, 2009.

27. Hygienic Standards GN 2.1.6.695-98; Maximal Allowable Concentrations (MAC) of the Pollutants in the Atmospheric air. RF Ministry for Health: Moscow, Russia, 1998.

28. Adcock, K.E.; Reeves, C.E.; Gooch, L.J.; Leedham Elvidge, E.C.; Ashfold, M.J.; Brenninkmeijer, C.A.; Chou, C.; Fraser, P.J.; Langenfelds, R.L.; Mohd Hanif, N.; et al. Continued increase of CFC-113a (CCl3CF3) mixing ratios in the global atmosphere: Emissions, occurrence and potential sources. Atmos. Chem. Phys. 2018, 18, 4737-4751. [CrossRef]

29. Prinn, R.G.; Weiss, R.F.; Arduini, J.; Arnold, T.; Fraser, P.J.; Ganesan, A.L.; Gasore, J.; Harth, C.M.; Hermansen, O.; Kim, J.; et al. The ALE/GAGE/AGAGE Data Base. Available online: http://agage.mit.edu/data and https://agage2.eas.gatech.edu/data_ archive/data_figures/global/pdf/CFC-113_glb.pdf (accessed on 27 April 2021). 
30. Yu, Z.; Li, Y. Marine volatile organic compounds and their impacts on marine aerosol—A review. Sci. Total Environ. 2021, 768, 145054. [CrossRef] [PubMed]

31. Ballschmiter, K. Pattern and sources of naturally produced organohalogens in the marine environment: Biogenic formation of organohalogens. Chemosphere 2003, 52, 313-324. [CrossRef]

32. Kurihara, M.; Iseda, M.; Ioriya, T.; Horimoto, N.; Kanda, J.; Ishimaru, T.; Yamaguchi, Y.; Hashimoto, S. Brominated methane compounds and isoprene in surface seawater of Sagami Bay: Concentrations, fluxes, and relationships with phytoplankton assemblages. Mar. Chem. 2012, 134-135, 71-79. [CrossRef]

33. Shibazaki, A.; Ambiru, K.; Kurihara, M.; Tamegai, H.; Hashimoto, S. Phytoplankton as a temperate marine source of brominated methanes. Mar. Chem. 2016, 181, 44-50. [CrossRef]

34. Chemicals of Emerging Arctic Concern. Summary for Policy-Makers; Arctic Monitoring and Assessment Programme (AMAP): Oslo, Norway, 2017; 16p.

35. Kosyakov, D.S.; Ul'yanovskii, N.V.; Mazur, D.M.; Lebedev, A.T. Mass spectrometry in the study of air pollution in the Arctic. Lab. Pro. 2020, 13, 56-68. (In Russian) [CrossRef]

36. Hansen, A.M.K.; Kristensen, K.; Nguyen, Q.T.; Zare, A.; Cozzi, F.; Nøjgaard, J.K.; Skov, H.; Brandt, J.; Christensen, J.H.; Ström, J.; et al. Organosulfates and organic acids in Arctic aerosols: Speciation, annual variation and concentration levels. Atmos. Chem. Phys. 2014, 14, 7807-7823. [CrossRef]

37. Simoneit, B.R.T. Biomass burning-a review of organic tracers for smoke from incomplete combustion. Appl. Geochem. 2002, 17, 129-162. [CrossRef]

38. Polyakova, O.V.; Artaev, V.B.; Lebedev, A.T. Priority and emerging pollutants in the Moscow rain. Sci. Total Environ. 2018, 645, 1126-1134. [CrossRef]

39. Polyakova, O.V.; Mazur, D.M.; Seregina, I.F.; Bolshov, M.A.; Lebedev, A.T. Estimation of contamination of atmosphere of Moscow in winter. J. Anal. Chem. 2012, 67, 1039-1049. [CrossRef]

40. Lebedev, A.T.; Polyakova, O.V.; Mazur, D.M.; Artaev, V.B.; Canet, I.; Lallement, A.; Vaïtilingom, M.; Deguillaume, L.; Delort, A.-M. Detection of semi-volatile compounds in cloud waters by GC-GC-TOFMS. Evidence of phenols and phthalates as priority pollutants. Environ. Pollut. 2018, 241, 616-625. [CrossRef] [PubMed]

41. United States Environmental Protection Agency: Assessing and Managing Chemicals under TSCA. Available online: https: //www.epa.gov/assessing-and-managing-chemicals-under-tsca/phthalates (accessed on 20 April 2021).

42. Salapasidou, M.; Samara, C.; Voutsa, D. Endocrine disrupting compounds in the atmosphere of the urban area of Thessaloniki, Greece. Atmos. Environ. 2011, 45, 3720-3729. [CrossRef]

43. Mazur, D.M.; Detenchuk, E.A.; Sosnova, A.A.; Artaev, V.B.; Lebedev, A.T. GC-HRMS with Complementary Ionization Techniques for Target and Non-target Screening for Chemical Exposure: Expanding the Insights of the Air Pollution Markers in Moscow Snow. Sci. Total Environ. 2021, 761, 144506. [CrossRef] [PubMed]

44. Khaustov, A.; Redina, M. Polycyclic aromatic hydrocarbons in the snow cover of Moscow (case study of the RUDN University campus). Polycycl. Aromat. Compd. 2019. [CrossRef]

45. He, J.; Balasubramanian, R. Semi-volatile organic compounds (SVOCs) in ambient air and rainwater in a tropical environment: Concentrations and temporal and seasonal trends. Chemosphere 2010, 78, 742-751. [CrossRef]

46. Pokryshkin, S.A.; Kosyakov, D.S.; Kozhevnikov, A.Y.; Lakhmanov, D.E.; Ul'yanovskii, N.V. Highly Sensitive Determination of Chlorophenols in Sea Water by Gas Chromatography-Tandem Mass Spectrometry. J. Anal. Chem. 2018, 73, 991-998. [CrossRef] 